\title{
Vitamin D status and its determinants in children and adults among families in late summer in Denmark
}

\author{
Katja H. Madsen ${ }^{1 *}$, Lone B. Rasmussen ${ }^{1}$, Heddie Mejborn ${ }^{1}$, Elisabeth W. Andersen ${ }^{2}$, \\ Christian Mølgaard ${ }^{3,4}$, Janna Nissen ${ }^{1}$, Inge Tetens ${ }^{1}$ and Rikke Andersen ${ }^{1}$ \\ ${ }^{1}$ Division of Nutrition, National Food Institute, Technical University of Denmark, Mørkhøj Bygade 19, DK-2860 Søborg, \\ Denmark \\ ${ }^{2}$ Department of Applied Mathematics and Computer Science, Technical University of Denmark, DK-2800 Lyngby, Denmark \\ ${ }^{3}$ Department of Nutrition, Exercise and Sports, Faculty of Science, University of Copenhagen, DK-1958 Frederiksberg C, \\ Denmark \\ ${ }^{4}$ Hans Christian Andersen Children's Hospital, Odense University Hospital, DK-500O Odense C, Denmark \\ (Submitted 2 July 2013 - Final revision received 31 March 2014 - Accepted 2 May 2014 - First published online 16 June 2014)
}

\begin{abstract}
The impact of the familial relationship on vitamin D status has not been investigated previously. The objective of the present cross-sectional study was to assess serum 25-hydroxyvitamin D (25(OH)D) concentration and its determinants in children and adults among families in late summer in Denmark $\left(56^{\circ} \mathrm{N}\right)$. Data obtained from 755 apparently healthy children $(4-17$ years) and adults (18-60 years) recruited as families ( $n$ 200) in the VitmaD study were analysed. Blood samples were collected in September-October, and serum $25(\mathrm{OH}) \mathrm{D}$ concentration was measured by liquid chromatography-tandem MS. Information on potential determinants was obtained using questionnaires. The geometric mean serum 25(OH)D concentration was 72.1 (interquartile range $61 \cdot 5-86 \cdot 7) \mathrm{nmol} / \mathrm{l}(\mathrm{range} 9-162 \mathrm{nmol} / \mathrm{l}$ ), with $9 \%$ of the subjects having $25(\mathrm{OH}) \mathrm{D}$ concentrations $<50 \mathrm{nmol} / \mathrm{l}$. The intra-family correlation was $0 \cdot 27$ in all subjects, $0 \cdot 24$ in the adults and $0 \cdot 42$ in the children. Serum $25(\mathrm{OH}) \mathrm{D}$ concentration was negatively associated with BMI $(P<0 \cdot 001)$ and positively associated with dietary vitamin D intake $(P=0 \cdot 008)$, multivitamin use $(P=0 \cdot 019)$, solarium use $(P=0 \cdot 006)$, outdoor stay $(P=0 \cdot 001)$, sun preference $(P=0 \cdot 002)$ and sun vacation $(P<0.001)$, but was not associated with lifestyle-related factors in the adults when these were assessed together with the other determinants. In conclusion, the majority of children and adults among the families had serum $25(\mathrm{OH}) \mathrm{D}$ concentrations $>50 \mathrm{nmol} / \mathrm{l}$ in late summer in Denmark. Both dietary and sun-related factors were determinants of vitamin D status and the familial component was stronger for the children than for the adults.
\end{abstract}

Key words: Serum 25-hydroxyvitamin D: Determinants: Families

The importance of vitamin $\mathrm{D}$ in bone health is recognised with rickets in children and osteomalacia and osteoporosis in adults being the traditional clinical conditions associated with vitamin $\mathrm{D}$ deficiency ${ }^{(1,2)}$. Furthermore, the expression of vitamin $D$ receptors in different tissues ${ }^{(3)}$ indicates additional biological functions of the vitamin. Low vitamin D status has been reported to be associated with a range of health outcomes ${ }^{(4,5)}$, including an increased risk of cardiometabolic disorders $^{(6)}$, some cancers ${ }^{(7)}$, autoimmune diseases ${ }^{(8)}$ and mortality ${ }^{(9)}$. However, it is still unclear whether these associations are causal. Studies have found vitamin D status to be associated with sociodemographic and lifestyle-related factors $^{(10,11)}$; thus, vitamin D status may serve as an indicator of general health and/or lifestyle.
The accepted biomarker of vitamin D status is 25-hydroxyvitamin $\mathrm{D}(25(\mathrm{OH}) \mathrm{D})$ concentration in the blood $^{(12)}$. In Denmark, the following values are used to define deficient, insufficient and sufficient serum $25(\mathrm{OH}) \mathrm{D}$ concentrations: $<25 ; 25-50 ;>50 \mathrm{nmol} / \mathrm{l}^{(13)}$. The Institute of Medicine (USA) has defined $30 \mathrm{nmol} / \mathrm{l}$ as the limit beyond which adverse effects on bone might occur ${ }^{(14)}$. Serum $25(\mathrm{OH}) \mathrm{D}$ concentrations of 40 and $50 \mathrm{nmol} / 1$ have been considered to represent the estimated average requirement and the recommended daily allowance, which are assumed to meet the requirement in the average population and the majority of the population for bone health. A threshold value $>125 \mathrm{nmol} / 1$ has been considered to be the at-risk value for harm by the Institute of Medicine (USA).

Abbreviations: 25(OH)D, 25-hydroxyvitamin D; DEQAS, Vitamin D External Quality Assessment Scheme; IQR, interquartile range; LC-MS/MS, liquid chromatography-tandem MS; NIST, National Institute of Standards and Technology; PTH, parathyroid hormone.

*Corresponding author: K. H. Madsen, fax +45358871 19, email kjma@food.dtu.dk 
The use of cut-off values and the comparison of vitamin D status between studies are complicated due to variations in measurements between the methods as well as among the laboratories using the same $25(\mathrm{OH}) \mathrm{D}$ assay ${ }^{(15-17)}$. In 2010, the National Institute of Standards and Technology (NIST) introduced a standard reference material for the measurement of vitamin D concentrations in human serum ${ }^{(18)}$, which is expected to improve the analytical performance of $25(\mathrm{OH}) \mathrm{D}$ measurements and to facilitate harmonisation across $25(\mathrm{OH}) \mathrm{D}$ assays ${ }^{(15)}$.

Thus, there is a need for comparative data on vitamin D status yielded by standardised and calibrated methods to better compare vitamin D status between population groups and evaluate the current situation of vitamin D deficiency. Vitamin D status has been measured in different population groups in Denmark ${ }^{(10,19-23)}$. None of the previous studies has assessed a broad range of age and sex groups in both children and adults. Especially, there is a lack of data on vitamin D status in young boys. One of the studies has reported vitamin D status in men, women and girls from Danish immigrant families ${ }^{(23)}$. However, to our knowledge, no previous studies have quantified the impact of the familial relationship on vitamin D status. This knowledge on vitamin D status within families will be helpful when considering strategies to improve vitamin D status.

The objective of the present study was to assess serum $25(\mathrm{OH}) \mathrm{D}$ concentration and its determinants in children and adults among families in late summer in Denmark.

\section{Subjects and methods}

\section{Study population}

The present cross-sectional study used baseline data obtained from the VitmaD study ${ }^{(24)}$ conducted in Denmark $\left(56^{\circ} \mathrm{N}\right)$. Children and adults were recruited as families randomly drawn from the Danish Civil Registration System. Inclusion criteria were age between 4 and 60 years and a permanent address in Gladsaxe Municipality. Exclusion criteria were pregnancy and disease or use of medication influencing vitamin D metabolism (including dietary supplements with vitamin D levels $>10 \mu \mathrm{g} / \mathrm{d}$ for children and $>5 \mu \mathrm{g} / \mathrm{d}$ for adults, which correspond to the typical levels in multivitamin supplements in Denmark). Of the 782 recruited children and adults, 755 (representing 200 families) had their serum $25(\mathrm{OH}) \mathrm{D}$ concentration measured and complete questionnaire data at baseline. The present analyses were conducted on these subjects. Written informed consent was obtained from all the adult subjects and from the guardians of the children. The study was conducted according to the guidelines laid down in the Declaration of Helsinki, and all procedures involving human subjects were approved by the Research Ethics Committee of the Capital Region of Denmark (record no. H-4-2010-020) and registered in ClinicalTrials.gov (NCT01184716).

\section{Methods}

The subjects were examined and their blood samples were collected in September-October 2010 in an authorised laboratory (Copenhagen's General Practitioners Laboratory, Søborg, Denmark). The weight of the subjects was measured to the nearest $0 \cdot 1 \mathrm{~kg}$ in normal clothes without shoes $(1 \mathrm{~kg}$ was subtracted from the measured weight) with a body composition analyser (Tanita BC-418; Tanita Europe B.V.). Height was measured to the nearest centimetre without shoes with an ultrasonic height measure (Soehnle 5001; Soehnle Professional $\mathrm{GmbH} \&$ Company). BMI was calculated based on the measured weight and height, and the subjects were categorised into normal-weight, overweight and obese classes according to the standards for children ${ }^{(25)}$ and the WHO International standard for adults ${ }^{(26)}$. Non-fasting venous blood samples were drawn from the subjects, and serum and plasma were collected and stored at $-80^{\circ} \mathrm{C}$ until analysis.

Serum 25(OH)D concentration was measured at the Clinical Biochemical Department, Holbæk Hospital, Denmark, using isotope dilution liquid chromatography-tandem MS (LCMS/MS) according to the principles described elsewhere ${ }^{(27)}$ The method was calibrated against the NIST standard for the analysis of vitamin D in human serum (standard reference material 972) ${ }^{(16)}$, and the inter-assay CV for the method used in the present study were $2 \cdot 2$ and $2 \cdot 8 \%$ at 30 and $180 \mathrm{nmol} / 1$, respectively, for $25(\mathrm{OH}) \mathrm{D}_{3}$ and 7.6 and $4.6 \%$ at 43 and $150 \mathrm{nmol} / 1$, respectively, for $25(\mathrm{OH}) \mathrm{D}_{2}$. The analytical quality of this method was ensured through participation in the Vitamin D External Quality Assessment Scheme (DEQAS). In this validation scheme, the mean bias for our method compared with the mean of the DEQAS LC-MS group during the period the present analyses were carried out was $-3 \cdot 2 \%$. Plasma parathyroid hormone (PTH) concentration was measured using an immunology analyser (Cobas e601; Roche Diagnostics), according to the standard procedures of the manufacturer $(\mathrm{CV}=3 \cdot 4 \%)$.

Information on background, health, sun exposure and lifestyle, including the use of multivitamin and vitamin D supplements, of the subjects was obtained using detailed self-administered web-based questionnaires. Dietary vitamin D intakes were recorded using a semi-quantitative FFQ adapted from a FFQ used in the European union project Towards a strategy for Optimal Vitamin D Fortification (OPTIFORD) ${ }^{(23)}$. The vitamin D intakes were calculated based on the reported consumption frequencies and the vitamin D concentrations in the food items given in the Danish Food Composition Databank ${ }^{(28)}$.

\section{Statistical analyses}

Data were analysed using the SPSS statistical software (version 20.0, IBM SPSS, Inc.), and statistical significance was evaluated at a level of $P<0.05$ (two-sided). Linear mixed models with family as a random variable were used in all the analyses to account for the non-independency of the subjects. Before analysis, serum 25(OH)D and PTH concentrations were logarithmically transformed to meet the model requirements. Trend analyses were carried out to test for linear relationships between PTH concentrations and 25(OH)D groups. Univariate models were used to assess the association between serum $25(\mathrm{OH}) \mathrm{D}$ concentration and each of the following sun-related variables: outdoor transport to school/work $(<15,15-30$, 
Table 1. Characteristics of the study population ( $n$ 755)

(Number of subjects and percentages)

\begin{tabular}{|c|c|c|c|c|c|c|}
\hline & \multicolumn{2}{|c|}{ All subjects } & \multicolumn{2}{|c|}{ Children } & \multicolumn{2}{|c|}{ Adults } \\
\hline & $n$ & $\%$ & $n$ & $\%$ & $n$ & $\%$ \\
\hline \multicolumn{7}{|l|}{ Sex } \\
\hline Female & 386 & 51 & 178 & 52 & 208 & 50 \\
\hline Male & 369 & 49 & 162 & 48 & 207 & 50 \\
\hline \multicolumn{7}{|l|}{ Age (years) } \\
\hline $4-10$ & 179 & 24 & 179 & 53 & - & - \\
\hline $11-17$ & 161 & 21 & 161 & 47 & - & - \\
\hline $18-40$ & 198 & 26 & - & - & 198 & 48 \\
\hline $41-60$ & 217 & 29 & - & - & 217 & 52 \\
\hline \multicolumn{7}{|l|}{$\mathrm{BMI}\left(\mathrm{kg} / \mathrm{m}^{2}\right)$} \\
\hline Obese & 54 & 7 & 1 & $<1$ & 53 & 13 \\
\hline Overweight & 156 & 21 & 20 & 6 & 136 & 33 \\
\hline Normal weight & 545 & 72 & 319 & 94 & 226 & 55 \\
\hline \multicolumn{7}{|c|}{ Dietary vitamin $D^{*}(\mu \mathrm{g} / \mathrm{d})$} \\
\hline Q1: $<1.7$ & 186 & 25 & 85 & 25 & 101 & 24 \\
\hline Q2: $1 \cdot 7-2 \cdot 4$ & 193 & 25 & 83 & 24 & 110 & 27 \\
\hline Q3: $2 \cdot 5-3 \cdot 3$ & 186 & 25 & 93 & 27 & 93 & 22 \\
\hline Q4: $>3.3$ & 190 & 25 & 79 & 23 & 111 & 27 \\
\hline \multicolumn{7}{|l|}{ Multivitamin use } \\
\hline Yes & 244 & 32 & 140 & 41 & 104 & 25 \\
\hline No & 511 & 68 & 200 & 59 & 311 & 75 \\
\hline \multicolumn{7}{|c|}{ Outdoor transport to school/work $(\mathrm{min} / \mathrm{d})$} \\
\hline$<15$ & 369 & 50 & 162 & 48 & 207 & 51 \\
\hline $15-30$ & 236 & 32 & 132 & 39 & 104 & 26 \\
\hline $31-60$ & 95 & 13 & 36 & 11 & 59 & 15 \\
\hline$>60$ & 43 & 6 & 10 & 3 & 33 & 8 \\
\hline \multicolumn{7}{|l|}{ Solarium use } \\
\hline Yes & 12 & 2 & 2 & $<1$ & 10 & 2 \\
\hline No & 743 & 98 & 338 & 99 & 405 & 98 \\
\hline \multicolumn{7}{|c|}{ Outdoor stay in light clothes } \\
\hline Most of the time & 408 & 54 & 199 & 59 & 209 & 50 \\
\hline Often & 273 & 36 & 116 & 34 & 157 & 38 \\
\hline Sometimes & 62 & 8 & 18 & 5 & 44 & 11 \\
\hline Seldom/never & 12 & 2 & 7 & 2 & 5 & 1 \\
\hline \multicolumn{7}{|l|}{ Sun preference } \\
\hline Prefer sun & 246 & 33 & 103 & 30 & 143 & 35 \\
\hline Sometimes in sun & 467 & 62 & 222 & 65 & 245 & 59 \\
\hline Avoid sun & 42 & 6 & 15 & 4 & 27 & 7 \\
\hline \multicolumn{7}{|l|}{ Sunscreen use } \\
\hline Always & 68 & 9 & 47 & 14 & 21 & 5 \\
\hline Most of the time & 274 & 36 & 169 & 50 & 105 & 25 \\
\hline Sometimes & 224 & 30 & 80 & 24 & 144 & 35 \\
\hline Seldom/never & 189 & 25 & 44 & 13 & 145 & 35 \\
\hline \multicolumn{7}{|l|}{ Sun vacation } \\
\hline Yes & 363 & 48 & 168 & 49 & 195 & 47 \\
\hline No & 392 & 52 & 172 & 51 & 220 & 53 \\
\hline
\end{tabular}

* $Q$ uartiles $(Q)$ for the whole study population.

$31-60$, or $>60 \mathrm{~min} / \mathrm{d}$ ); solarium use at least once a week (yes or no); sun preference (prefer sun, sometimes in sun, or avoid sun); outdoor stay in light clothes (most of the time, often, sometimes, or seldom/never); sunscreen use (always, most of the time, sometimes, or seldom/never); sun vacation the preceding summer in June-September (yes or no). Sunrelated variables with $P<0.05$ significance in their univariate model were included in a multiple analysis (linear mixed model) together with the following categorical variables: age (4-10, 11-17, 18-40, or 41-60 years); sex (female or male); BMI (normal weight, overweight, or obese); dietary vitamin $\mathrm{D}$ intake (quartiles: $<1 \cdot 7,1 \cdot 7-2 \cdot 4,2 \cdot 5-3 \cdot 3$, or $>3.3 \mu \mathrm{g} / \mathrm{d}$ ); multivitamin use (yes or no). The interaction between age and sex was tested. This multiple analysis was carried out for all subjects and for children and adults separately. The strength of the familial component was considered by calculating the intra-class correlation for each model:

$$
\rho=\frac{\omega^{2}}{\left(\omega^{2}+\sigma^{2}\right)},
$$

where $\rho$ is the intra-family correlation, $\sigma$ is the within-family standard deviation and $\omega$ is the between-family standard deviation. The lower the variation within the classes, the higher the intra-class correlation, which in this case means that the closer the correlation is to 1 , the more alike the subjects are within a family with respect to their vitamin D status.

The relationship between serum $25(\mathrm{OH}) \mathrm{D}$ concentration and each of the following lifestyle-related variables was explored in univariate models only in adults: smoking status (current, former, or never); alcohol consumption (never, $<1$ time/month, 1-3 times/month, 1 time/week, 2-4 times/ week, 5-6 times/week, or daily); leisure-time physical activity (mainly sedentary, light-to-moderate activity, regular sport and exercise, or athletic training); self-rated physical shape (really good, good, fairly good, bad, or really bad); self-rated health

Table 2. Lifestyle-related characteristics of adults in the study population (n 415)

(Number of subjects and percentages)

\begin{tabular}{|c|c|c|}
\hline & $n$ & $\%$ \\
\hline \multicolumn{3}{|l|}{ Education } \\
\hline None/technical & 115 & 28 \\
\hline$<3$ years of higher education & 59 & 14 \\
\hline $3-4$ years of higher education & 133 & 32 \\
\hline$>4$ years of higher education & 108 & 26 \\
\hline \multicolumn{3}{|l|}{ Smoking status } \\
\hline Current & 77 & 19 \\
\hline Former & 106 & 26 \\
\hline Never & 232 & 56 \\
\hline \multicolumn{3}{|l|}{ Alcohol consumption } \\
\hline Never & 19 & 5 \\
\hline$<1$ time/month & 61 & 15 \\
\hline $1-3$ times/month & 103 & 25 \\
\hline 1 time/week & 67 & 16 \\
\hline 2-4 times/week & 124 & 30 \\
\hline $5-6$ times/week & 27 & 7 \\
\hline Daily & 14 & 3 \\
\hline \multicolumn{3}{|l|}{ Leisure-time physical activity } \\
\hline Mainly sedentary & 44 & 11 \\
\hline Light-to-moderate activity & 155 & 37 \\
\hline Regular sports and exercise & 168 & 41 \\
\hline Athletic training & 48 & 12 \\
\hline \multicolumn{3}{|l|}{ Self-rated physical shape } \\
\hline Really good & 29 & 7 \\
\hline Good & 154 & 37 \\
\hline Fairly good & 167 & 40 \\
\hline Bad & 53 & 13 \\
\hline Really bad & 12 & 3 \\
\hline \multicolumn{3}{|l|}{ Self-rated health } \\
\hline Excellent & 51 & 12 \\
\hline Really good & 167 & 40 \\
\hline Good & 170 & 41 \\
\hline Less good/bad & 27 & 7 \\
\hline \multicolumn{3}{|l|}{ Effort to eat healthily } \\
\hline Very often & 125 & 30 \\
\hline Often & 211 & 51 \\
\hline Sometimes & 65 & 16 \\
\hline Seldom/never & 14 & 3 \\
\hline
\end{tabular}


(excellent, really good, good, or less good/bad); effort to eat healthily (very often, often, sometimes, or seldom/ never); education after state and/or upper secondary school (none or technical education, $<3$ years of higher education, 3-4 years of higher education, or $>4$ years of higher education). Lifestyle-related variables with $P<0.05$ significance in their univariate model were included in the multiple model described above.

\section{Results}

The characteristics of the study population and the lifestylerelated characteristics of adults in the study population are given in Tables 1 and 2, respectively. The median ages of the youngest children (4-10 years), the oldest children (11-17 years), the youngest adults (18-40 years) and the oldest adults (41-60 years) were 7 (interquartile range (IQR) 6-9), 13 (IQR 12-15), 37 (IQR 33-39) and 45 (IQR 43-48) years, respectively. The sexes were evenly distributed among both the children and adults, and the majority of the subjects were of normal weight (Table 1 ). The median dietary vitamin $\mathrm{D}$ intakes were similar across the age groups (range $2.3-2.6 \mu \mathrm{g} / \mathrm{d}$ ). The total median vitamin $\mathrm{D}$ intake of the multivitamin users ( $41 \%$ of the children and $25 \%$ of the adults) was 6.7 (IQR $4.5-10 \cdot 2) \mu \mathrm{g} / \mathrm{d}$. Approximately half of the adults had a medium-long- to long-duration higher education, and their lifestyles were generally healthy (Table 2).

The individual serum $25(\mathrm{OH}) \mathrm{D}$ concentrations (sum of $25(\mathrm{OH}) \mathrm{D}_{2}$ and $25(\mathrm{OH}) \mathrm{D}_{3}$ concentrations) ranged from $9 \cdot 3$ to $161.9 \mathrm{nmol} / 1$, with an overall geometric mean of $72 \cdot 1$ (IQR 61.5-86.7) nmol/1. Serum $25(\mathrm{OH}) \mathrm{D}_{2}$ was found in $11 \%$ of the samples in the range of $3-29 \mathrm{nmol} / \mathrm{l}$. The serum $25(\mathrm{OH}) \mathrm{D}$ concentration of the different age and sex groups and its distribution across the ranges are summarised in Table 3. The overall distribution of serum 25(OH)D concentrations $<30,<40$ and $<50 \mathrm{nmol} / 1$ was 1,2 and $9 \%$, with no children being found to have serum $25(\mathrm{OH}) \mathrm{D}$ concentration $<30 \mathrm{nmol} / 1$. In the adults, the geometric mean PTH concentrations in the $25(\mathrm{OH}) \mathrm{D}$ concentration $<25,25-49$, 50-75 and $>75 \mathrm{nmol} / 1$ groups were $59 \cdot 8$ (95\% CI $43 \cdot 2$, 82.8), 39.9 (95\% CI 35.8, 44.3), 36.2 (95\% CI 34.3, 38.2) and 32.7 (95\% CI $31 \cdot 1,34.4) \mathrm{ng} / \mathrm{l}$, respectively ( $P$ for trend $<0.001)$. The same trend was observed in children aged 4-10 years ( $P$ for trend $=0 \cdot 012$ ), but not in children aged $11-17$ years $(P$ for trend $=0.067)$.

No differences were found in serum 25(OH)D concentration among the age $(P=0 \cdot 190)$, sex $(P=0 \cdot 332)$ or age, and sex groups $(P=0 \cdot 223)$ in the multiple analysis of all subjects (Table 4). When the children were analysed separately, serum 25(OH)D concentration was found to be associated with sex $(P=0.034)$ and so $25(\mathrm{OH}) \mathrm{D}$ concentration was estimated to be $5 \%$ lower in the girls than in the boys. In the univariate models, outdoor transport to work/school $(P=0.972)$ and sunscreen use $(P=0.154)$ were not associated with $25(\mathrm{OH}) \mathrm{D}$ concentration and thus not included in the multiple models. In the multiple analysis of all subjects, serum $25(\mathrm{OH}) \mathrm{D}$ concentration was found to be negatively associated with BMI $(P<0.001)$ and positively associated

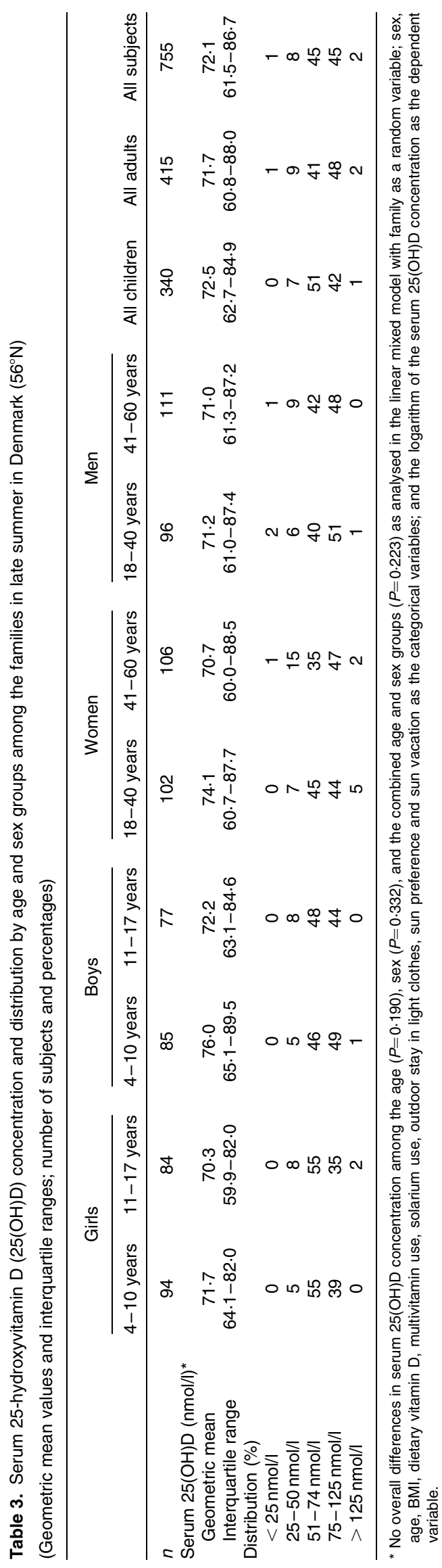


Table 4. Associations between potential determinants and serum 25-hydroxyvitamin $\mathrm{D}(25(\mathrm{OH}) \mathrm{D})$ concentration* (Ratio of means and $95 \%$ confidence interval)

\begin{tabular}{|c|c|c|c|c|c|c|c|c|c|}
\hline \multirow[b]{2}{*}{ Variables } & \multicolumn{3}{|c|}{ All subjects $(n 755)$} & \multicolumn{3}{|c|}{ Children ( $n$ 340) } & \multicolumn{3}{|c|}{ Adults ( $n$ 415) } \\
\hline & Ratio of meanst & $95 \% \mathrm{Cl}$ & $P$ & Ratio of means $\dagger$ & $95 \% \mathrm{Cl}$ & $P$ & Ratio of means $\dagger$ & $95 \% \mathrm{Cl}$ & $P$ \\
\hline Sex & & & 0.332 & & & 0.034 & & & 0.792 \\
\hline Female & 0.98 & $0.95,1.02$ & & 0.95 & $0.91,1.00$ & & 1.01 & $0.96,1.06$ & \\
\hline Male & 1 & 1 & & 1 & 1 & & 1 & 1 & \\
\hline Age (years) & & & 0.190 & & & 0.823 & & & 0.937 \\
\hline $4-10$ & 0.99 & $0.94,1.05$ & 0.778 & 1.01 & $0.96,1.06$ & & - & - & \\
\hline $11-17$ & 0.95 & $0.91,1.01$ & 0.082 & 1 & 1 & & - & - & \\
\hline $18-40$ & 1.01 & $0.96,1.07$ & 0.653 & - & - & & 1.00 & $0.94,1.06$ & \\
\hline $41-60$ & 1 & 1 & & - & - & & 1 & 1 & \\
\hline BMI $\left(\mathrm{kg} / \mathrm{m}^{2}\right)$ & & & $<0.001$ & & & 0.348 & & & 0.001 \\
\hline Obese & 0.83 & $0.77,0.90$ & $<0.001$ & 0.97 & $0.61,1.54$ & 0.908 & 0.84 & $0.77,0.92$ & $<0.001$ \\
\hline Overweight & 0.97 & $0.92,1.02$ & 0.173 & 0.93 & $0.85,1.03$ & 0.148 & 0.98 & $0.92,1.04$ & 0.519 \\
\hline Normal weight & 1 & 1 & & 1 & 1 & & 1 & 1 & \\
\hline Dietary vitamin $D \ddagger(\mu \mathrm{g} / \mathrm{d})$ & & & 0.008 & & & 0.065 & & & 0.034 \\
\hline Q1: $<1.7$ & 0.92 & $0.87,0.97$ & 0.002 & 0.94 & $0.88,1.00$ & 0.068 & 0.91 & $0.84,0.98$ & 0.015 \\
\hline Q2: $1.7-2 \cdot 4$ & 0.97 & $0.92,1.02$ & 0.284 & 0.95 & $0.88,1.01$ & 0.104 & 1.00 & $0.93,1.08$ & 0.982 \\
\hline Q3: $2 \cdot 5-3 \cdot 3$ & 1.00 & $0.95,1.05$ & 0.927 & 1.01 & $0.95,1.08$ & 0.741 & 0.99 & $0.92,1.08$ & 0.899 \\
\hline Q4: $>3.3$ & 1 & 1 & & 1 & 1 & & 1 & 1 & \\
\hline Multivitamin use & & & 0.019 & & & 0.066 & & & 0.045 \\
\hline Yes & 1.06 & $1.01,1 \cdot 10$ & & 1.05 & $1.00,1 \cdot 11$ & & 1.07 & $1.00,1.14$ & \\
\hline No & 1 & 1 & & 1 & 1 & & 1 & 1 & \\
\hline Solarium use & & & 0.006 & & & 0.199 & & & 0.007 \\
\hline Yes & $1 \cdot 2$ & $1.06,1.43$ & & 0.82 & $0.61,1.11$ & & 1.29 & $1.07,1.55$ & \\
\hline No & 1 & 1 & & 1 & 1 & & 1 & 1 & \\
\hline Outdoor stay in light clothes & & & 0.001 & & & 0.013 & & & $<0.001$ \\
\hline Most of the time & $1 \cdot 30$ & $1.11,1.51$ & 0.001 & $1 \cdot 20$ & $1.01,1.43$ & 0.034 & 1.58 & $1 \cdot 20,2.08$ & 0.001 \\
\hline Often & 1.29 & $1.11,1.50$ & 0.001 & 1.25 & $1.05,1.49$ & 0.011 & 1.51 & $1.15,2.00$ & 0.003 \\
\hline Sometimes & $1 \cdot 16$ & $0.99,1.36$ & 0.063 & 1.32 & $1.10,1.59$ & 0.004 & 1.29 & $0.97,1.71$ & 0.083 \\
\hline Never/seldom & 1 & 1 & & 1 & 1 & & 1 & 1 & \\
\hline Sun preference & & & 0.002 & & & 0.621 & & & 0.001 \\
\hline Prefer sun & $1 \cdot 14$ & $1.04,1.25$ & 0.004 & 0.96 & $0.85,1.09$ & 0.570 & $1 \cdot 24$ & $1.09,1.40$ & 0.001 \\
\hline Sometimes in sun & 1.07 & $0.98,1.17$ & 0.116 & 0.95 & $0.84,1.07$ & 0.393 & 1.14 & $1.01,1.29$ & 0.034 \\
\hline Avoid sun & 1 & 1 & & 1 & 1 & & 1 & 1 & \\
\hline Sun vacation & & & $<0.001$ & & & $<0.001$ & & & 0.021 \\
\hline Yes & 1.09 & $1.04,1.15$ & & $1 \cdot 11$ & $1.06,1.17$ & & 1.07 & $1.01,1.14$ & \\
\hline No & 1 & 1 & & 1 & 1 & & 1 & 1 & \\
\hline
\end{tabular}

*Analysed in the linear mixed models with family as a random variable; sex, age, BMI, dietary vitamin D, multivitamin use, solarium use, outdoor stay in light clothes, sun preference and sun vacation as the categorical variables; and the logarithm of the serum $25(\mathrm{OH}) \mathrm{D}$ concentration as the dependent variable.

$\ddagger$ Quartiles (Q) for the whole study population. 
with dietary vitamin $\mathrm{D}$ intake $(P=0.008)$, multivitamin use $(P=0 \cdot 019)$, solarium use $(P=0 \cdot 006)$, outdoor stay in light clothes $(P=0.001)$, sun preference $(P=0.002)$ and sun vacation $(P<0.001)$ (Table 4$)$. When the children and adults were analysed separately, serum $25(\mathrm{OH}) \mathrm{D}$ concentration was found to be associated with BMI and sun preference in the children. In the adults, the associations remained the same as in the model with all subjects, but the significance for dietary vitamin $\mathrm{D}$ intake, multivitamin use and sun vacation was weakened.

From these multivariate models, it was found that the variations in serum $25(\mathrm{OH}) \mathrm{D}$ concentration were higher within the families than between the families with an intra-family correlation of $0 \cdot 27$ in all subjects. The intra-family correlation was higher in the children than in the adults (Table 5).

In a further analysis of the adults, serum 25(OH)D concentration was found to be associated with leisure-time physical activity $(P<0 \cdot 001)$, self-rated physical shape $(P=0 \cdot 001)$ and self-rated health $(P=0.003)$ in their univariate models. When these variables were included in the multiple analysis together with the vitamin D source-related variables, none remained significant, although leisure-time physical activity was borderline significant $(P=0.054)$. Serum $25(\mathrm{OH}) \mathrm{D}$ concentration was not associated with smoking status $(P=0 \cdot 722)$, alcohol consumption $(P=0 \cdot 070)$, effort to eat healthily $(P=0.193)$ or education $(P=0 \cdot 219)$.

\section{Discussion}

The overall geometric mean serum 25(OH)D concentration among the families in the present study was $72 \cdot 1 \mathrm{nmol} / \mathrm{l}$, with no differences being observed between the age and sex groups in the analysis of all subjects. The distribution of $25(\mathrm{OH}) \mathrm{D}$ concentrations $<25,<50$ and $<75 \mathrm{nmol} / \mathrm{l}$ was 1 , 8 and $54 \%$, with no children being found with $25(\mathrm{OH}) \mathrm{D}$ concentration $<25 \mathrm{nmol} / \mathrm{l}$. A novelty of the present study was that the familial component was quantitatively assessed by calculating the intra-class correlation. The intra-family correlation for all subjects was $0 \cdot 27$, which indicates that a subject's vitamin D status is not strongly related to the familial relationship. However, to our knowledge, no previous studies have quantified the familial component for vitamin D status and thus we do not have a value for comparison of the familial

Table 5. Standard deviation for the within-family and between-family effects and the intra-family correlation*

\begin{tabular}{lccc}
\hline Parameters & $\begin{array}{c}\text { All subjects } \\
(n \text { 755) }\end{array}$ & $\begin{array}{c}\text { Children } \\
(n \text { 340) }\end{array}$ & $\begin{array}{c}\text { Adults } \\
(n \text { 415) }\end{array}$ \\
\hline Between-family standard deviation & 0.060 & 0.063 & 0.061 \\
Within-family standard deviation & 0.098 & 0.074 & 0.11 \\
Intra-family correlationt & 0.27 & 0.42 & 0.24 \\
\hline
\end{tabular}

* Derived from the linear mixed models with family as a random variable; sex, age, BMI, dietary vitamin D, multivitamin use, solarium use, outdoor stay in light clothes, sun preference, and sun vacation as the categorical variables; and the logarithm of the serum 25-hydroxyvitamin D concentration as the dependent variable.

†Calculated as follows: between-family standard deviation ${ }^{2} /($ between-family standard deviation ${ }^{2}+$ within-family standard deviation ${ }^{2}$ ). relationship. The intra-family correlation was almost double in the children $(0.42)$ as in the adults $(0.24)$, indicating that the children within a family were more alike than the adults within a family with respect to their vitamin D status. This might be an indication of the influence of genetic factors on vitamin D status or more similar habits in children than in adults from the same family. It is likely that children within a family share activities and dietary/supplementation habits to a greater extent than adults within a family, e.g. outdoor stay, sun protection, multivitamin use and lunch in school.

The serum 25(OH)D concentrations found in the present study were higher and the distribution of $25(\mathrm{OH}) \mathrm{D}$ concentrations $<50 \mathrm{nmol} / \mathrm{l}$ was lower than that reported in previous studies among similar age and ethnicity groups in Denmark $^{(10,20-23)}$, other European countries ${ }^{(11,23,29-33)}$, the $\mathrm{USA}^{(34,35)}$ and Canada ${ }^{(36)}$. Most of these studies measured vitamin D status across different seasons or in the winter as opposed to late summer in the present study; however, the distribution of $25(\mathrm{OH}) \mathrm{D}$ concentrations $<50 \mathrm{nmol} / 1$ found in the present study was also lower than that found during summer. Most of the participants of the present study were of normal weight, which could favourably affect the serum $25(\mathrm{OH}) \mathrm{D}$ concentration compared with, for example, the high rate of obesity in the USA ${ }^{(37)}$. Nevertheless, the studies should be compared with caution as differences may also depend on the laboratory and method used for the measurement of serum $25(\mathrm{OH}) \mathrm{D}$ concentrations ${ }^{(17)}$. In the present study, we used the LC-MS/MS method that might be considered the gold standard ${ }^{(38,39)}$, and our method was standardised and calibrated against the international reference material of the $\mathrm{NIST}^{(18)}$. The chromatographic methods are more specific compared with the frequently used immunoassays that are limited in their ability to detect vitamin $\mathrm{D}_{2}^{(38,40)}$. In the DEQAS, the LC-MS method is positively biased for the all-laboratory trimmed mean, whereas the immunoassays are mostly negatively biased ${ }^{(17)}$. Several studies have also found the LC-MS method to yield better results than some other $25(\mathrm{OH}) \mathrm{D}$ assays ${ }^{(15,16,39-41)}$. In a study of the German population, standardisation to the LC-MS/MS method has been found to reduce the prevalence of vitamin $\mathrm{D}$ deficiency $(<30 \mathrm{nmol} / \mathrm{l})$ from approximately 48 to $16 \%{ }^{(42)}$. This might partly explain the higher serum $25(\mathrm{OH}) \mathrm{D}$ concentrations found in the present study compared with previous studies in similar population groups.

Similar to the common finding of an inverse relationship between $25(\mathrm{OH}) \mathrm{D}$ and PTH concentrations ${ }^{(43)}$, we observed a negative trend between PTH and $25(\mathrm{OH}) \mathrm{D}$ groups in the adults and in children aged 4-10 years. In present study, relatively few subjects had a low serum 25(OH)D concentration $(<25 \mathrm{nmol} / \mathrm{l})$, but the PTH concentration was markedly higher in this group than in the other 25(OH)D groups. Elevated PTH concentrations may result in increased bone resorption in adults, whereas the implication for bone health in children is unclear ${ }^{(44)}$

For all subjects, outdoor stay in light clothes and sun vacation were major determinants of serum $25(\mathrm{OH}) \mathrm{D}$ concentration in late summer. In the adults, sun preference, solarium use and BMI were also strong determinants. We expected 
vitamin D status to be related to sun exposure as cutaneous vitamin $\mathrm{D}$ synthesis is considered to be the major source of vitamin D during summer ${ }^{(45)}$. It is interesting though that several expressions of sun exposure were related to serum $25(\mathrm{OH}) \mathrm{D}$ concentrations at the same time. Most suggestive may be that vitamin D status was associated with sun vacation (abroad), despite that the hours of sunshine the preceding summer (2010) in Denmark were only slightly less than (3\%) the average hours of sunshine in the preceding 10 years $^{(46)}$. To our knowledge, this association between vitamin $\mathrm{D}$ status and sun vacation during the summer season has not been shown previously. The dietary vitamin D intake was also associated with serum $25(\mathrm{OH}) \mathrm{D}$ concentration in the present study, despite the median intake $(2.5 \mu \mathrm{g} / \mathrm{d})$ being much lower than the new recommended intake proposed by the Nordic Nutrition Recommendation. The recommended intake has recently been increased from 7.5 to $10 \mu \mathrm{g} / \mathrm{d}$ for 2- to 60 -year-olds ${ }^{(47)}$. This makes room for an even greater improvement in vitamin D intake, and our finding suggests that dietary vitamin D intake is also important during summer even in a group of children and adults frequently staying outdoors.

In the present study, no association between vitamin D status and age was found. Some previous studies have shown an association between vitamin D status and age in both children ${ }^{(35)}$ and adults ${ }^{(11)}$, whereas others did not find an association between $25(\mathrm{OH}) \mathrm{D}$ concentration and age $^{(10,31,32)}$. The observed higher vitamin $\mathrm{D}$ status in boys than in girls has been reported previously among similar age groups $^{(48)}$. In the present study, this sex difference was not attributable to differences in dietary vitamin D intakes or multivitamin use. An explanation might be the higher level of physical activity in the boys than in the girls $(56 \%$ of the boys compared with $35 \%$ of the girls reported to be involved in sports and physically active play activities in their leisure time; results not shown), assuming that these activities were primarily outdoor activities. Serum 25(OH)D concentration was strongly inversely related to BMI in the adults, whereas there was no association in the children. This might be because the children were not categorised as obese and only a few were overweight. Another study in healthy-weight children with a broad age span did not find an association between $25(\mathrm{OH}) \mathrm{D}$ concentration and BMI or fat mass either ${ }^{(35)}$. The association between $25(\mathrm{OH}) \mathrm{D}$ concentration and obesity is a common finding ${ }^{(11,34,49)}$, and one explanation could be the sequestration of vitamin $\mathrm{D}$ in fat tissue $^{(50)}$. In a cross-sectional study of 686 adults, adjusting for body weight eliminated the obesity-related component of variability in serum $25(\mathrm{OH}) \mathrm{D}$ concentrations ${ }^{(51)}$. This indicates that the lower $25(\mathrm{OH}) \mathrm{D}$ concentration could be due to dilution in the large fat mass of obese subjects rather than sequestration and that vitamin $\mathrm{D}$ requirements could be based on body weight.

In the adults, serum $25(\mathrm{OH}) \mathrm{D}$ concentration was not related to lifestyle when assessed together with the influence of vitamin D source-related factors, except for a borderline relationship with leisure-time physical activity. It might be that physical activity acts like a surrogate marker for sun exposure, assuming that the activities are mainly outdoor activities. Previous studies have found an association between $25(\mathrm{OH}) \mathrm{D}$ concentration and various lifestyle-related factors $^{(10,11)}$. In one study, an overall lifestyle index was used and vitamin D concentrations were found to be substantially higher in those with the healthiest lifestyle than in those with a less-healthy lifestyle and this difference was found be substantially higher than that between the single components of the lifestyle index ${ }^{(11)}$. This suggests that a high vitamin D concentration may serve as an indicator of a generally healthy lifestyle.

The strength of the present study was the random and population-based inclusion of families, which made it possible to compare vitamin D status across the age and sex groups. This has not been done previously in studies of the Danish population. Another strength was the use of detailed information on vitamin D sources including several variables for sun exposure, dietary vitamin D intake and supplement use. A limitation of the present study was that it was conducted at a single site in Denmark. However, the sample size of the present study was large and the subjects were randomly selected with few exclusion criteria, and we believe that the results are likely to be generalisable.

We assessed vitamin D status in a representative sample of Danish families using a standardised and calibrated method, and thus the results are useful for future comparisons of vitamin D status between populations. In conclusion, the majority of children and adults among the families had serum 25(OH)D concentrations $>50 \mathrm{nmol} / \mathrm{l}$ in late summer in Denmark. Vitamin D status was associated with BMI, dietary vitamin D intake, multivitamin use, solarium use, outdoor stay in light clothes, sun preference and sun vacation, but was not associated with lifestyle-related factors in the adults when these were assessed together with the other determinants. Children within a family appeared to be more alike than the adults within a family with respect to their vitamin D status.

\section{Acknowledgements}

The authors are grateful to the families for their active and enthusiastic participation. They thank the students of the Metropolitan University College and the University of Copenhagen for assisting in the examination of the participants and the staff at Copenhagen's General Practitioners Laboratory for collecting the blood samples. They cordially thank the VitmaD project team and other colleagues at the Division of Nutrition, National Food Institute, Technical University of Denmark, for their assistance during the planning and implementation of the study and for helpful professional discussions.

The present study was supported by grants from the Danish Dairy Research Fund, Centre for Advanced Food Studies, and the European Regional Development Fund. The funders had no role in the design and analysis of the study or in the writing of this article.

The authors' contributions are as follows: I. T., R. A., H. M., K. H. M., L. B. R. and C. M. designed the study; H. M., J. N., K. H. M., L. B. R. and R. A. conducted the study; E. W. A., K. H. M., L. B. R. and R. A. analysed the data; K. H. M. 
wrote the first draft of the manuscript, which was critically reviewed and approved by all authors.

None of the authors has any conflicts of interest to declare.

\section{References}

1. Holick MF (2007) Vitamin D deficiency. N Engl J Med 357, 266-281.

2. Sahota O (2000) Osteoporosis and the role of vitamin D and calcium-vitamin D deficiency, vitamin D insufficiency and vitamin D sufficiency. Age Ageing 29, 301-304.

3. Wang Y, Zhu J \& DeLuca HF (2012) Where is the vitamin D receptor? Arch Biochem Biophys 523, 123-133.

4. Grant WB (2006) Epidemiology of disease risks in relation to vitamin D insufficiency. Prog Biophys Mol Biol 92, 65-79.

5. Wacker M \& Holick MF (2013) Vitamin D - effects on skeletal and extraskeletal health and the need for supplementation. Nutrients 5, 111-148.

6. Parker J, Hashmi O, Dutton D, et al. (2010) Levels of vitamin D and cardiometabolic disorders: systematic review and meta-analysis. Maturitas 65, 225-236.

7. Gandini S, Boniol M, Haukka J, et al. (2011) Meta-analysis of observational studies of serum 25-hydroxyvitamin D levels and colorectal, breast and prostate cancer and colorectal adenoma. Int J Cancer 128, 1414-1424.

8. Kriegel MA, Manson JE \& Costenbader KH (2011) Does vitamin D affect risk of developing autoimmune disease?: a systematic review. Semin Arthritis Rheum 40, 512-531.

9. Zittermann A, Iodice S, Pilz S, et al. (2012) Vitamin D deficiency and mortality risk in the general population: a meta-analysis of prospective cohort studies. Am J Clin Nutr 95, 91-100.

10. Thuesen B, Husemoen L, Fenger M, et al. (2012) Determinants of vitamin D status in a general population of Danish adults. Bone 50, 605-610.

11. Jaaskelainen T, Knekt P, Marniemi J, et al. (2013) Vitamin D status is associated with sociodemographic factors, lifestyle and metabolic health. Eur J Nutr 52, 513-525.

12. Seamans KM \& Cashman KD (2009) Existing and potentially novel functional markers of vitamin D status: a systematic review. Am J Clin Nutr 89, 1997S-2008S.

13. National Board of Health (2010) Forebyggelse, diagnostik og behandling af D-vitaminmangel (Prevention, Diagnostics and Treatment of Vitamin D Deficiency). National Board of Health. Copenhagen: National Board of Health. http:// www.sst.dk/ /media/Sundhed\%20og\%20forebyggelse/ Ernaering/D-vitamin/D-vitamin\%20baggrundsnotat\%2027052010.ashx (accessed April 2013).

14. Food and Nutrition Board, Institute of Medicine (2011) Dietary Reference Intakes for Calcium and Vitamin D. Washington, DC: National Academy Press.

15. Farrell CL, Martin S, McWhinney B, et al. (2012) Stateof-the-art vitamin D assays: a comparison of automated immunoassays with liquid chromatography-tandem mass spectrometry methods. Clin Chem 58, 531-542.

16. Lai JKC, Lucas RM, Banks E, et al. (2012) Variability in vitamin D assays impairs clinical assessment of vitamin D status. Intern Med J 42, 43-50.

17. Carter GD (2011) Accuracy of 25-hydroxyvitamin D assays: confronting the issues. Curr Drug Targets 12, 19-28.

18. Phinney KW, Bedner M, Tai SS, et al. (2012) Development and certification of a standard reference material for vitamin D metabolites in human serum. Anal Chem 84, 956-962.

19. Brot C, Vestergaard P, Kolthoff N, et al. (2001) Vitamin D status and its adequacy in healthy Danish perimenopausal women: relationships to dietary intake, sun exposure and serum parathyroid hormone. Br J Nutr 86, Suppl. 1, S97-S103.

20. Mølgaard C, Larnkjær A, Cashman KD, et al. (2010) Does vitamin D supplementation of healthy Danish Caucasian girls affect bone turnover and bone mineralization? Bone 46, 432-439.

21. Skaaby T, Husemoen LL, Pisinger C, et al. (2013) Vitamin D status and incident cardiovascular disease and all-cause mortality: a general population study. Endocrine $\mathbf{4 3}$ 618-625.

22. Andersen R, Mølgaard C, Skovgaard LT, et al. (2005) Teenage girls and elderly women living in northern Europe have low winter vitamin D status. Eur J Clin Nutr 59, 533-541.

23. Andersen R, Mølgaard C, Skovgaard LT, et al. (2008) Pakistani immigrant children and adults in Denmark have severely low vitamin D status. Eur J Clin Nutr 62, 625-634.

24. Madsen KH, Rasmussen LB, Andersen R, et al. (2013) Randomized controlled trial of the effects of vitamin D-fortified milk and bread on serum 25-hydroxyvitamin D concentrations in families in Denmark during winter: the VitmaD study. Am J Clin Nutr 98, 374-382.

25. Cole TJ, Bellizzi MC, Flegal KM, et al. (2000) Establishing a standard definition for child overweight and obesity worldwide: international survey. BMJ 320, 1240-1243.

26. World Health Organization (2000) Obesity: Preventing and Managing the Global Epidemic. Report of a WHO Consultation (WHO Technical Report Series 894). Geneva: WHO.

27. Blomberg Jensen M, Bjerrum PJ, Jessen TE, et al. (2011) Vitamin D is positively associated with sperm motility and increases intracellular calcium in human spermatozoa. Hum Reprod 26, 1307-1317.

28. National Food Institute, Technical University of Denmark (2009) Danish Food Composition Databank, Version 7.01. Mørkhøj: National Food Institute. http://www.foodcomp.dk/ v7/fvdb_search.asp (accessed April 2012).

29. Gonzalez-Gross M, Valtuena J, Breidenassel C, et al. (2012) Vitamin D status among adolescents in Europe: the healthy lifestyle in Europe by nutrition in adolescence study. BrJ Nutr 107, 755-764.

30. Cashman KD, Muldowney S, McNulty B, et al. (2013) Vitamin D status of Irish adults: findings from the National Adult Nutrition Survey. Br J Nutr 109, 1248-1256.

31. Hirani V, Mosdol A \& Mishra G (2009) Predictors of 25-hydroxyvitamin D status among adults in two British national surveys. Br J Nutr 101, 760-764.

32. Hintzpeter B, Mensink GBM, Thierfelder W, et al. (2008) Vitamin D status and health correlates among German adults. Eur J Clin Nutr 62, 1079-1089.

33. Hill TR, Cotter AA, Mitchell S, et al. (2008) Vitamin D status and its determinants in adolescents from the Northern Ireland Young Hearts 2000 cohort. Br J Nutr 99, 1061-1067.

34. Forrest KYJ \& Stuhldreher WL (2011) Prevalence and correlates of vitamin D deficiency in US adults. Nutr Res $\mathbf{3 1}$ 48-54.

35. Weng FL, Shults J, Leonard MB, et al. (2007) Risk factors for low serum 25-hydroxyvitamin D concentrations in otherwise healthy children and adolescents. Am J Clin Nutr 86, 150-158.

36. Whiting SJ, Langlois KA, Vatanparast H, et al. (2011) The vitamin D status of Canadians relative to the 2011 Dietary Reference Intakes: an examination in children and adults with and without supplement use. Am J Clin Nutr 94, 128-135.

37. OECD (2011) Health at a Glance 2011: OECD Indicators, OECD Publishing. Paris: OECD. http://dx.doi.org/10.1787/ health_glance-2011-en (accessed October 2013). 
38. Fraser WD \& Milan AM (2013) Vitamin D assays: past and present debates, difficulties, and developments. Calcif Tissue Int 92, 118-127.

39. Roth HJ, Schmidt-Gayk H, Weber H, et al. (2008) Accuracy and clinical implications of seven 25-hydroxyvitamin D methods compared with liquid chromatography-tandem mass spectrometry as a reference. Ann Clin Biochem 45, $153-159$

40. van den Ouweland JMW, Vogeser M \& Baecher S (2013) Vitamin D and metabolites measurement by tandem mass spectrometry. Rev Endocr Metab Disord 14, 159-184.

41. Moon H, Cho J, Hur M, et al. (2012) Comparison of four current 25-hydroxyvitamin D assays. Clin Biochem 45, 326-330

42. Perna L, Haug U, Schoettker B, et al. (2012) Public health implications of standardized 25-hydroxyvitamin D levels: a decrease in the prevalence of vitamin $\mathrm{D}$ deficiency among older women in Germany. Prev Med 55, $228-232$

43. Sai AJ, Walters RW, Fang X, et al. (2011) Relationship between vitamin $\mathrm{D}$, parathyroid hormone, and bone health. J Clin Endocrinol Metab 96, E436-E446.

44. Cashman KD (2007) Vitamin D in childhood and adolescence. Postgrad Med J 83, 230-235.
45. Macdonald HM (2013) Contributions of sunlight and diet to vitamin D status. Calcif Tissue Int 92, 163-176.

46. The Danish Institute of Meteorology (2010) Vejret i Danmarksommeren 2010 (The Weather in Denmark - The Summer of 2010). Copenhagen: The Danish Institute of Meteorology. http://www.dmi.dk/dmi/vejr_i_danmark_-_sommeren_2010 (accessed April 2013).

47. Nordic Council of Ministers (2014) Nordic Nutrition Recommendations 2012 - Integrating Nutrition and Physical Activity. Copenhagen: Nordic Council of Ministers.

48. Rockell JE, Green TJ, Skeaff CM, et al. (2005) Season and ethnicity are determinants of serum 25-hydroxyvitamin D concentrations in New Zealand children aged 5-14 y. J Nutr 135, 2602-2608.

49. Bertrand KA, Giovannucci E, Liu Y, et al. (2012) Determinants of plasma 25-hydroxyvitamin $\mathrm{D}$ and development of prediction models in three US cohorts. BrJ Nutr 108, 1889-1896.

50. Wortsman J, Matsuoka L, Chen T, et al. (2000) Decreased bioavailability of vitamin D in obesity. Am J Clin Nutr $\mathbf{7 2}$, 690-693.

51. Drincic AT, Armas LA, Van Diest EE, et al. (2012) Volumetric dilution, rather than sequestration best explains the low vitamin D status of obesity. Obesity 20, 1444-1448. 